\title{
Refugees Who Arrive by Boat and Canada's Commitment to the Refugee Convention: A Discursive Analysis
}

\author{
Alexandra ManN
}

\section{Abstract}

This paper offers a comparative analysis of official discourse surrounding three incidents of asylum seekers arriving in Canada by boat: the Komagata Maru in 1914; the Sri Lankans who arrived in Newfoundland on lifeboats in 1986; and the Ocean Lady in 2009. The objective is to assess Canada's commitment to protecting refugees at these three points in history and evaluate academic contentions that the concept of the refugee is being eroded. The selected incidents trace the emergence and decline of the notion of the refugee in Canadian official discourse. Even during the peak of Canada's commitment to refugees in the 1980s, the discourse reveals blurriness between the ideas of the "refugee" and the "illegal migrant." However, the characterization of asylum seekers as "illegals" is more intense now than in the earlier periods. This shift in the discourse warrants attention as we face the prospect of what Audrey Macklin describes as the "discursive disappearance of the refugee."

\section{Résumé}

Le présent article propose une analyse comparative $d u$ discours officiel entourant trois cas de demandeurs d'asile arrivant par bateau au Canada : l'incident $d u$ Komagata Maru en 1914, les Sri-Lankais qui sont arrivés à TerreNeuve sur des embarcations de sauvetage en 1986 et l'incident $d u$ Ocean Lady en 2009. L'objectif est d'évaluer l'engagement du Canada à protéger les réfugiés à ces trois moments de l'histoire et d'évaluer les arguments théoriques voulant une érosion de la notion de réfugié. Les incidents choisis suivent l'émergence et le déclin de la notion de réfugié dans le discours officiel canadien. Même au plus fort de l'engagement du Canada envers les réfugiés dans les années 1980, le discours se révèle flou sur les notions de «réfugié» et de "migrant clandestin». Cependant, la caractérisation des demandeurs d'asile comme «clandestins" est plus intense aujourd'hui que par les périodes antérieures. Ce changement dans le discours justifie qu'on $y$ porte attention alors que nous faisons face à la perspective de ce que Audrey Macklin décrit comme la «disparition discursive du réfugié».

\section{Introduction}

In Humanitarianism, Identity, and Nation: Migration Laws of Australia and Canada, Catherine Dauvergne argues that Canada has an international reputation as a country with generous immigration laws and a history of offering protection to refugees. Contemporary Canada, says Dauvergne, has to some extent been "created" by immigration and the mythology of immigration forms an integral part of Canada's national identity. ${ }^{1}$ Compared to other "immigrant nations," such as Australia, Canada has a strong tradition of granting protection to those who meet the definition of "refugee" in the 1951 Convention relating to the Status of Refugees (hereafter the Refugee Convention). ${ }^{2}$ This tradition, says Dauvergne, is linked to humanitarianism, which is a value that Canadians as individuals are willing to honour by upholding the country's commitment to provide asylum to those fleeing persecution. ${ }^{3}$

In recent years, however, immigration and refugee scholars have observed that Canada is becoming more hostile to asylum seekers than it was in the past. ${ }^{4}$ In "Disappearing Refugees: Reflections on the Canada-U.S. Safe Third Country Agreement," Audrey Macklin argues that the very concept of the refugee is being eroded in Canadian society and replaced with the image of the illegal migrant. Macklin explains that this "discursive disappearance of the refugee" is propelled by growing concerns about national security and the rise in interdiction measures. As developed countries like Canada make it more difficult for asylum seekers 
to enter their territories, individuals fleeing persecution are forced to cross borders secretly, often with the assistance of human smugglers, in order to avoid being detected by authorities. Macklin notes that while it is widely recognized that millions of people are living in situations that would make them eligible for refugee protection under Canadian law, as soon as they cross the Canadian border they become illegals. Unlike refugees, who have a right to make a claim for protection, illegals are transgressors who are perceived as unworthy of Canada's compassion. ${ }^{5}$

Dauvergne similarly argues that Canada has played a part in transforming refugees into illegals in spite of its humanitarian tradition. Like Macklin, Dauvergne links this process to concerns about security risks and the intensification of border control. She argues that when refugees are reconceptualized as illegals, they are viewed as criminals, and thus do not trigger the same discursive responses that refugees have in recent history. Dauvergne reflects that while the late twentieth century was marked by the emergence of a commitment to humanitarianism, the twenty-first century may be marked by the rise of border control. ${ }^{6}$

In this paper, I assess the validity of Macklin's and Dauvergne's observations by analyzing the official discourse surrounding three incidents in which asylum seekers entered Canadian territory by boat. The objective of the analysis is to assess Canada's commitment to the cause of refugees at these three points in history and evaluate whether the idea of the refugee is in fact being eroded and replaced with the concept of the illegal immigrant.

Incidents involving refugees arriving by boat tend to elicit strong public and political responses in comparison to refugees who arrive by other modes of transportation. Commentators note that refugees who arrive by boat gain a disproportionate amount of media attention, considering that they represent only a small percentage of asylum seekers who enter Canada by illegal means in order to make a claim for protection. ${ }^{7}$ There is something evocative about the image of asylum seekers arriving by boat that attracts peoples' attention and generates discussion among public officials about the country's immigration and refugee policies. For this reason, the arrivals of refugees by boat offer material for a discursive analysis of Canada's commitment to refugees.

Although asylum seekers have travelled to Canada by boat on a number of occasions, I will limit my analysis to the following three incidents: the Komagata Maru, which arrived in British Columbia carrying 376 migrants from British-controlled India in 1914; the two lifeboats carrying 155 Sri Lankan Tamils who were rescued off the coast of Newfoundland in 1986; and the Ocean Lady, which arrived in British Columbia carrying 76 Sri Lankan Tamils in 2009.
I have selected these three incidents because they attracted a significant amount of media attention and generated political discussion. These incidents also share a common feature in that they involve asylum seekers of South Asian origin. Therefore, differences between the official discourses surrounding each of the incidents cannot be attributed to the asylum seekers' ethnicities.

I chose the 1914 Komagata Maru incident as my starting point because it provides a picture of how Canada responded to asylum seekers prior to the coming into force of the Refugee Convention. The official discourse surrounding this event thus illustrates how Canada perceived asylum seekers before the legal concept of the refugee came into existence. I selected the 1986 incident because it took place after Canada became a signatory to the Refugee Convention and during a period which is now regarded as the heyday of Canadian refugee policy. The year 1986 was the year in which the United Nations awarded Canada the Nansen medal in recognition of its commitment to protecting refugees. In the preceding ten-year period, Canada had brought over 150,000 refugees to be resettled in Canada, which was more per capita than any other country. ${ }^{8}$ The official discourse surrounding this incident exemplifies how Canada conceptualized the refugee during the height of the country's commitment to protecting those fleeing from persecution. For the third incident, I selected the arrival of the Ocean Lady in 2009 because it is the most recent high-profile incident involving refugees coming to Canada by boat. The Ocean Lady incident thus provides an opportunity to consider the current state of Canada's commitment to refugees. With the two earlier incidents as points of reference, I assess whether the official discourse surrounding the Ocean Lady indicates that Canada is becoming more hostile to asylum seekers, and whether the notion of the refugee is being eroded.

Another reason why I selected these three incidents is that they all involve individuals fleeing circumstances of widespread persecution in their home countries. In 1914, the British-controlled Indian government persecuted Indian citizens who were involved, or perceived to be involved, in the movement for Indian independence. Several of the passengers of the Komagata Maru were in fact persecuted on this basis when the Canadian government forced them to return to India. It is therefore likely that they came to Canada with a well-founded fear of persecution. For this reason, it is appropriate to include the arrival of the Komagata Maru in this analysis of Canada's commitment to protecting refugees even though the event predates the coming into force of the Refugee Convention.

The second and third incidents both involve the arrival of Sri Lankan Tamils during a period when Tamils suffered 
widespread persecution at the hands of the Sri Lankan government due to their ethnicity and their real or perceived involvement in the movement for an independent Tamil state. This persecution has been especially prevalent since the beginning of the Sri Lankan civil war in $1983 .{ }^{9}$ Though the war technically ended in May of 2009, several months before the arrival of the Ocean Lady, reports indicate that the Sri Lankan government has continued to persecute Tamils. For example, the government has kept emergency legislation in place that permits warrantless searches and extended detentions of Tamils without criminal charges. ${ }^{10}$ Given this context, it is likely that the Tamils who came to Canada by boat in 1986 and in 2009 had a well-founded fear of persecution.

\section{Outline and Methodology}

In Parts I, II, and III of this paper, I detail the events of the Komagata Maru incident, the 1986 incident, and the Ocean Lady incident. In each section, I discuss the official discourse surrounding the events focusing on public and/ or intragovernmental statements by the key politicians who were responsible for immigration at the relevant time. My aim was to find out what the officials said about the incidents, how they characterized the asylum seekers, and how they related the incidents to broader immigration and refugee policy issues.

In Part I, I draw exclusively upon secondary sources that provide historical accounts of the Komagata Maru incident. The officials whose statements I discuss include: Prime Minister Sir Robert Borden; Malcolm Reid, head of the Vancouver immigration agency; and E. Blake Robertson, Assistant Superintendent of Immigration.

In Part II, I draw upon secondary sources as well as newspaper articles about the 1986 incident. I identified the newspaper articles with Canadian Newsstand, which is a ProQuest database of nine major Canadian daily newspapers. The officials whose statements I discuss include: Prime Minister Brian Mulroney; Benoît Bouchard, Minister of Employment and Immigration; and Gerry Weiner, Minister of State for Immigration.

In Part III, the section on the Ocean Lady incident, I draw on newspaper articles located through Canadian Newsstand as well as Hansard. In this section of the paper, I focus primarily on official statements by Jason Kenney, Minister of Citizenship and Immigration, because he was the government's primary spokesperson regarding the incident. However, I also include statements by Peter Van Loan, Minister of Public Safety, and Members of Parliament, such as MP Don Davies (Vancouver Kingsway, NDP), and MP Thierry St-Cyr (Jeanne-Le Ber, BQ), in order to provide a broader picture of the discourse surrounding the incident.
In the final section of the paper, I provide a comparative analysis of the official discourse surrounding each of the three incidents. I reflect on the differences and similarities between the statements and explore how the statements reflect Canada's stance toward asylum seekers at the three different points in history. In closing, I assess the extent to which my research indicates that Canada is becoming more hostile to refugees than it was in the past.

\section{Part I. The Komagata Maru Incident}

On May 23, 1914, a ship by the name of Komagata Maru arrived in British Columbia carrying 376 prospective immigrants from India. At the time, Canadian immigration laws included exclusionary provisions aimed at preventing Asians from immigrating to Canada. As a consequence, government officials refused to allow the passengers to land and forced them to return to India where they faced persecution and some even met their death. They were persecuted by the British-controlled Indian government due to their alleged involvement in the political movement for Indian independence. ${ }^{11}$ This incident is now remembered as a shameful moment in Canadian history when the government failed to offer protection to those fleeing persecution. ${ }^{12}$

On May 23, 2008, ninety-four years after the arrival of the Komagata Maru, the British Columbia legislature unanimously passed a motion apologizing for the deportation of the passengers. The spirit of the apology was captured by the statements of several members of the legislature. Liberal House Leader Mike de Jong stated: "( $t$ )his house deeply regrets that the passengers who sought refuge were turned away."13 B.C. Attorney General Wally Oppal said that what happened to the passengers is unimaginable today, and the government apologizes for the racism and suffering to which they were subjected. ${ }^{14}$

These official statements acknowledge that the deportation of the Komagata Maru passengers was unjust and that it is important to commemorate this event so that Canadians may remember the value of the refugee protection system that is now in place. It is worth noting, however, that to describe the Komagata Maru passengers as refugees who were wrongfully turned away is somewhat anachronistic. Although the concept of the refugee has existed for centuries, it was not until the signing of the Refugee Convention in 1951 that states undertook a legal obligation to offer refuge to those fleeing persecution..${ }^{15}$ Prior to the Refugee Convention, the right of asylum did not exist in law and was not reliably honoured. ${ }^{16}$ In the early twentieth century, state governments came to view the ancient right of asylum as outdated and in conflict with state sovereignty. ${ }^{17}$ When the Komagata Maru arrived in Canada in 1914, there was no legal distinction between immigrants and refugees; the immigration laws took no account 
of an individual's reasons for leaving their home country, but rather focused exclusively on whether they met the criteria to enter Canada as immigrants.

Since there was no legal concept of the refugee in 1914, the issue of whether or not the passengers were in need of protection did not enter the official discourse. The passengers did not raise their fear of persecution in their arguments for why Canada should admit them, and government officials did not address the possibility that the passengers could be subjected to harm upon their return to India. Instead, the debate focused on the legitimacy of the racist immigration laws that rendered the passengers inadmissible to Canada. ${ }^{18}$ The passengers, and those advocating on their behalf, argued that as British subjects, they should have the right to reside in other countries within the British Empire. The government's position was that that under the British North America Act (BNA), Canada had the authority to regulate immigration, which included the unfettered right to exclude undesirable classes of individuals regardless of their status as British subjects. ${ }^{19}$

In the House of Commons, it was uncontroversial that the Komagata Maru passengers should be deported and debate was limited to the questions of when and how they were to be removed. ${ }^{20}$ Public officials' statements reflected animosity toward the passengers, who were popularly viewed as part of an invasion of Indian migrants who were taking scarce jobs and threatening Canada's dominant Anglo culture. ${ }^{21}$ For example, Frank Oliver, a former Minister of the Interior, stated:

(t)o say that we in Canada shall not be able to say who shall join us in the work of building up the country, that we must accept the dictation of other people as to who shall join in that work, places us in the position not of a self-governing state in a free empire, but in the position of a subordinate dependency not in control of its own affairs. ${ }^{22}$

This statement exemplifies the government's strong defence of its unfettered right to determine who will be permitted to immigrate to Canada, and who will be excluded.

The passengers of the Komagata Maru were inadmissible to Canada as a result of three immigration laws designed to exclude migrants from the "Asiatic races": (1) P.C. 24, an order-in-council that required Asian immigrants to pay a $\$ 200$ fee upon entry; ${ }^{23}$ (2) P.C. 23 , the "continuous journey regulation," which stated that all immigrants to Canada must come directly from their country of origin by an uninterrupted journey ${ }^{24}$ (this regulation prevented immigration from India because there was no direct steamship service from South Asia to Canada at the time); ${ }^{25}$ and (3) P.C. 897, which prohibited migrant labourers from entering Canada through British Columbia (since the majority of migrant labourers seeking to enter British Columbia were Asian, this regulation also limited immigration from India). ${ }^{26}$

Ironically, it was because of these exclusionary provisions that the passengers of the Komagata Maru came to arrive in Canada. The voyage was organized by Gurdit Singh, a wealthy Indian migrant living in Hong Kong who wanted to challenge the three orders-in-council that prevented Indians from immigrating to Canada. ${ }^{27} \mathrm{He}$ was encouraged by a party of Indian migrants who had successfully challenged the validity of early versions of the orders-in-council the previous year. The court overturned the regulations on a technicality and the Cabinet immediately amended and reissued the orders. ${ }^{28}$

G. Singh chartered the Komagata Maru to transport a group of Indian migrants from Hong Kong to Canada. ${ }^{29}$ On May 23, when the Komagata Maru arrived near Vancouver, immigration authorities prevented it from docking. An immigration launch with armed guards perpetually circled the ship to ensure that the passengers remained on board. ${ }^{30}$ Some local politicians and immigration officials were in favour of deporting the passengers without giving them the opportunity to challenge their removal in the courts. Prime Minister Borden, however, did not approve of circumventing the legal process. Instead, he instructed the immigration board to complete its inquiry as soon as possible and issue a decision. On June 25, Borden sent a wire to Reid which stated:

(y)ou should take no step which in any way admits the jurisdiction of the Court to interfere, but if the immigrants initiate proceedings, it is important to secure a hearing before the Court which will give a reasonable construction to the Act and regulations. ${ }^{31}$

Borden's statement indicates that he hoped the passengers would not discover that they had a right to challenge the exclusion order in court. If they did apply for judicial review, however, he instructed Reid to ensure that the matter be decided by a court that would interpret the applicable laws in a "reasonable" manner. This implies that he wanted to avoid a repeat of the scenario in 1913 when a judge determined that the anti-Indian regulations were inoperative.

This interpretation is supported by Hugh J.M. Johnston's account of negotiations between government officials and G. Singh that resulted in the matter going straight to the British Columbia Court of Appeal, as opposed to being heard first at the lower court level. According to Johnston, the government was worried that in the lower court, there was a risk that the exclusion order would be reviewed by a rogue judge who might find a flaw in the orders-in-council. 
With a three-judge panel at the Court of Appeal, the risk was significantly lessened. ${ }^{32}$

A Vancouver-based organization called the United India League hired lawyers to challenge the exclusion order against one of the passengers, Munshi Singh, as a test case. ${ }^{33}$ The applicant's main argument was that Canada did not have authority under the BNA to exclude a British subject. However, the Court accepted the government's argument that s. 95 of the BNA granted Canada jurisdiction over immigration, which includes the right to define prohibited classes. Under this authority, the government had the power to exclude undesirable persons even if they were British subjects. ${ }^{34}$

After the Court issued its decision, Reid informed G. Singh that the Komagata Maru had to depart. ${ }^{35}$ The passengers refused, so immigration authorities limited deliveries of food and water to the ship in an effort to coerce them to leave. ${ }^{36}$ They were told that they would be given provisions at a point outside of Canadian waters. ${ }^{37}$ A skirmish broke out between the passengers and the police in which several people were injured but no one was killed. ${ }^{38}$

Official statements regarding the incident indicated a desire to quell public anxiety about the chaos surrounding the incident. According to Eric W. Morse, the public opinion in Vancouver was charged "to a fever-point" with anti-Indian sentiment. Residents sent wires to the government urging them to get rid of the Komagata Maru passengers, who were perceived as "invaders." 39 On July 20, the Assistant Superintendent of Immigration, E. Blake Robertson, issued a press notice saying that the navy vessel the HMCS Rainbow had been deployed "to effect a landing, when, if necessary, in order to secure and maintain control, the full number of Hindus will be handcuffed, a proceeding which in view of their violent actions last night, is fully justifiable." ${ }^{40}$ In this statement, Robertson communicated to the public that the Komagata Maru passengers were violent criminals who needed to be controlled.

The characterization of the passengers as criminals was also apparent in intragovernmental communications. For example, MP H.H. Stevens sent a wire to the Prime Minister in which he referred to the passengers as "desperately revolutionary and determined to defy law" and recommended that the navy take control of the situation. ${ }^{41}$ On July 21, Reid wired the Immigration Department in Ottawa:

(w)e urge immediate action owing to danger of anti-Oriental outbreaks in Vancouver when facts are made public. The men aboard are undoubtedly in a desperate and fanatical condition. It is utterly impossible to reason with them or to handle them in the ordinary manner. The peculiar situation of this riot occurring on board a ship anchored in the stream makes ordinary police methods utterly useless, as police and guards do not wish to use firearms to retaliate, and can do no effective service without. ${ }^{42}$

These official statements indicate that the focus was on how to get the ship to leave in the most peaceful fashion possible. The officials not only were concerned about violence among the passengers, but also were fearful of a violent "anti-Oriental" response from the public. On July 23, the navy deployed the HMCS Rainbow to escort the Komagata Maru out to sea while onlookers cheered. ${ }^{43}$

When the ship returned to Calcutta, India, it was greeted by the police. Some of the passengers were arrested, some were shot as they tried to escape, and the others became fugitives. ${ }^{44}$ By October 13, 1914, a total of 19 of the passengers were reported to have been killed. ${ }^{45}$ Subsequently, between April 1915 and May 1917, a series of trials targeting political agitators took place in India: 175 people were charged with political crimes, 20 were hanged, 76 were banished for life to India's convict colony, and 58 were imprisoned for shorter terms. ${ }^{46}$ At least two of the Komagata Maru passengers were among those convicted and sentenced, and others were subjected to suspicions which restricted their ability to work and move freely in the country. ${ }^{47}$

My review of the official discourse surrounding the Komagata Maru incident identifies three main themes: (1) defence of racist immigration policies; (2) lack of respect for procedural protections; and (3) fear of violence and criminality. The officials' statements clearly indicate that in 1914, Canada was not concerned with the plight of those fleeing from oppressive regimes such as British-controlled India. Although the modern concept of the "refugee" did not exist at the time, it is worthwhile to consider how Canadian officials reacted to the arrival of the Komagata Maru, as it provides a picture of how Canada reacted to people who were likely in need of asylum prior to the coming into force of the 1951 Refugee Convention. In the following section, which draws on secondary sources and my own review of newspaper articles, I will demonstrate how Canadian officials responded to the arrival of refugees by boat in 1986 .

\section{Part II. The 1986 Incident}

On August 11, 1986, $155^{48}$ Sri Lankan Tamils, including men, women, and children, were rescued by fishermen off the coast of Newfoundland after spending five days adrift in two lifeboats. ${ }^{49}$ The passengers told their rescuers through a translator that they came to Canada in the hope of escaping the violence of the civil war in their home country. ${ }^{50}$ The day after the Tamils were rescued, they were brought to St. John's where they were met by an emergency team of immigration officials who had been sent to conduct interviews. ${ }^{51}$ One hundred and forty-four were taken to the 
RCMP headquarters for questioning, after which they were taken to the residences at Memorial University for temporary accommodation. ${ }^{52}$ Once the interviews were complete, the refugees were taken to Toronto and Montreal to be connected with Tamil groups that had offered to find homes where they could stay. ${ }^{53}$

At the time, the Canadian government had a policy of not deporting individuals to certain refugee-producing countries. ${ }^{54}$ The list of designated countries, called the "B1 list," included Sri Lanka. ${ }^{55}$ Ottawa frequently issued one-year minister's permits to asylum seekers from the designated countries, which entitled them to live and work in Canada. The individual had the right to apply for refugee protection, or could simply apply to renew the permit at the end of the one-year period. Following this practice, the government issued minister's permits to the 155 Tamils almost immediately after they arrived. ${ }^{56}$ The Tamils' refugee applications were put on hold because the refugee determination system was undergoing a major overhaul. ${ }^{57}$

The decision to grant the minister's permits proved to be controversial and elicited criticism from Members of the Opposition and members of the public who felt that the government had acted too hastily in granting the Tamils legal status in Canada. ${ }^{58}$ Some Conservative MPs reported a flood of complaints from constituents complaining that the Tamils were being given preferential treatment over prospective immigrants seeking to enter Canada legally. ${ }^{59}$

In contrast to the Komagata Maru, my review of the official discourse surrounding the 1986 incident identifies humanitarianism as the dominant theme. Public officials also referred to the need for immigration reform and concerns about security and criminality, but these concerns were characterized as secondary to Canada's obligation to protect individuals fleeing from persecution.

Initially, the refugees indicated that they had come directly from Madras, India, despite evidence that their voyage originated in West Germany. For example, many of them had West German currency and their possessions were wrapped in West German newspapers. ${ }^{60}$ This contradiction led some to argue that the refugees should have been returned to West Germany. Progressive Conservative MP Jim Hawkes took this view when he stated: “(w)e can't have people, once they have escaped from persecution, simply shopping around for the country that's the most comfortable."61 This line of argument is premised on the idea that refugees are expected to claim asylum at the first opportunity. In other words, if a refugee claimant passes through one potential country of asylum to get to another, it is suspected that they are not fleeing persecution but are rather searching for economic opportunities. Following this reasoning, one could also argue that the Sri Lankans ought to have sought protection in India, but this argument did not appear in my research.

Bouchard announced that due to the government's policy of not deporting people to Sri Lanka, the refugees would have been given minister's permits even if it was confirmed that they came via West Germany. ${ }^{62}$ Gerry Weiner, Canada's Minister of State for Immigration, further explained the government's stance on this issue: "I have no difficulty right now in saying that they will be allowed to stay (whether their story is correct or not). There's no reason why these people should not be allowed to stay in our country." 63 This statement indicates that the government was willing to offer protection to the Tamils, even if they had lied about how they came to Canada.

It was eventually confirmed that at least some of the refugees had been living in West Germany and had submitted applications for refugee protection before they came to Canada. On August 16, Bouchard admitted that West Germany had alerted Canada to the smuggling operation long before the ship left for Canada. The West German authorities had learned of the operation from an anonymous caller, presumed to be a Sri Lankan refugee who had paid to be transported to Canada but had been left behind. ${ }^{64}$

In response to criticisms that the government should have acted on West Germany's warning, Bouchard stated that Ottawa was merely carrying out its policies with respect to Sri Lankan refugees. Referring to Canada's policy of not deporting individuals from the B1 list countries, Bouchard stated:

(i)f you have, for example, one boat a week in Newfoundland, what will you do? Until the change of the law, I cannot do anything else than what I did this week [ ... ] Personally, as a minister, I would not have accepted that human beings be left on boats for days on the pretext that we had not finished the inquiry into whether they were telling the truth or not (about whether their voyage began in India or West Germany. ${ }^{65}$

With this statement, Bouchard indicates that he decided to issue the minister's permits because he was required to do so by law. At the same time, he implies that if it had not been for the B1 list, he would have issued the permits due to the humanitarian nature of the situation. The result of these statements is a mixed message: on the one hand he defends the decision as morally correct, but on the other hand he blames the decision on the policy.

On August 17, a spokesperson for the 155 Tamils admitted that their voyage began in West Germany and not in India as they had originally claimed. He explained that the Tamils decided to come to Canada because as asylum 
seekers in West Germany they were subjected to oppressive conditions such as police harassment and policies that restricted their freedom of movement. They indicated that they decided to tell the truth after they had been granted minister permits and no longer feared being sent back to West Germany. ${ }^{66}$

On the same day, Prime Minister Brian Mulroney made his first public statement regarding the arrival of the 155 Tamils. In the face of public uproar over the Tamils' admission that they had lied to Canadian authorities, Mulroney strenuously defended the government's decision to grant them protection:

(m)y government will do anything but allow refugees in lifeboats to be turned aimlessly around in the ocean and turned away from our shores. [ ... ] We don't want people jumping to the head of the line. We don't want injustice introduced into the system. We don't want excessive delays. But there will always be human suffering and human misery and there will be people who come (to Canada) for freedom $[\ldots]$. And if we err ... we will always err on the side of justice and on the side of compassion. ${ }^{67}$

In response to calls for immigration reform, Mulroney stated that the government would examine current laws and policies and "tighten up procedures if required," but he emphasized that the need for reform was separate from the question of whether or not Canada would offer protection to refugees who arrive on its shores:

Canada was built by immigrants and refugees, and those who arrive in lifeboats off our shores are not going to be turned away. [ ... ] And it's not the presence of (155) frightened human beings searching for freedom and opportunity that's going to undermine Canada of our immigration policies. ${ }^{68}$

With these statements, Mulroney sends a clear message that Canada is committed to assisting refugees and that granting protection to individuals who travel to Canada illegally does not jeopardize the integrity of the immigration system. Mulroney also indicates that, given the high stakes involved for the individual, the government will presume that a refugee claimant's fears are well-founded until proven otherwise.

Mulroney's statement that Canada does not want people "jumping to the head of the line" appears to be an acknowledgement of the Opposition's criticism that Canada's generous refugee policies are unfair to people who wait patiently to immigrate to the country. Mulroney downplays these concerns by stressing Canada's obligation to protect refugees. Weiner, the Minister of State for Immigration, also addressed this critique by pointing out that "( $t$ )here's a difference between an immigrant and a refugee and a refugee cannot wait for a number." ${ }^{\prime 9}$ With this statement, Weiner supports Mulroney's position that refugee claimants do not undermine Canada's immigration system, and explains that refugees are not the same as immigrants. $\mathrm{He}$ recognizes that refugees by definition are fleeing persecution and sometimes have to leave their home country in urgent circumstances. Therefore, it is inappropriate to suggest that refugees are jumping the line.

The day after the 155 Tamils admitted that their trip began in West Germany, a West German radio station reported suspicions that they belonged to the Tamil Tigers, a Sri Lankan political organization that a number of countries have designated a terrorist group. ${ }^{70}$ Weiner rejected these suspicions as ill-founded: "We now have really a preliminary confirmation that none of these 155 fall into that category (of terrorists), that they are all refugees, that they are all ordinary citizens." ${ }^{71}$ At the same time, however, Weiner indicated that authorities were continuing security investigations to determine whether or not the Tamils were involved in any criminal activity: "(w)e began fingerprinting them all, and if there's any information that becomes available right now, then that will be acted on at once." 72 Weiner also stated that the policy of not deporting individuals to Sri Lanka can be disregarded in the case of criminals. ${ }^{73}$ Weiner's statements send the message that although the refugees are presumed to be innocent, Canadian law enforcement authorities are taking the appropriate steps to investigate whether any have criminal backgrounds.

Bouchard made similar comments in which he indicated that although Canada places a high value on humanitarianism, this value must be balanced against security concerns: "Canadians are as much concerned by security as they are by hospitality. We've had a tradition (of hospitality) in Canada but at the same time Canadians are getting to be perhaps a little bit more prudent and they want politicians to see exactly what's the involvement of such an adventure." 74 However, like Weiner, Bouchard stressed that there will be no "pre-judgment" of the asylum seekers and that questions about terrorism and other forms of criminality would be left to the RCMP. ${ }^{75}$

Although officials acknowledged concerns about the integrity of the immigration system and security threats, humanitarianism stood out as the overriding priority. On September 5, in response to continuing criticisms from the Opposition, Mulroney once again defended the decision to grant the minister's permits:

I won't quarrel with you in terms of some of the technical bureaucratic matters [ ... ] in the Tamil case. [ ... ] But the fundamental issue is, are refugees welcome in Canada and will we open our 
doors? The answer is yes. [ ... ] One of the saddest things that has happened to this country was during the '40s. Families and families and families of Jewish refugees seeking entry into Canada and they were turned away by red tape. That will never happen while Brian Mulroney is prime minister. ${ }^{76}$

With this statement, Mulroney emphasized Canada's commitment to humanitarianism and indicated that when in doubt, Canada will offer protection to those who seek it.

By August of 1991, five years after they arrived, the majority of the 155 Tamil refugees were still without permanent resident status in Canada. An estimated 90 per cent of them were still on minister's permits and were waiting for their refugee claims to be heard. Since they did not have permanent resident status, their situation remained precarious and they could not sponsor their family members to join them in Canada. ${ }^{77}$

As I have demonstrated in this section, the official discourse surrounding the arrival of the 155 Tamils in 1986 contrasts sharply with the Komagata Maru discourse. In 1914, official statements conveyed defence of Canada's exclusionary immigration laws and a desire to prevent the Komagata Maru passengers from gaining access to the courts. The officials characterized the passengers as criminals who posed a threat to public order, apparently because their presence was considered likely to ignite anti-Oriental riots. By contrast, the 1986 discourse focused on Canada's legal and moral commitment to protect refugees. Public officials suggested that when people come to Canada seeking asylum, they will be presumed to be refugees in the absence of evidence that they are not in need of protection or are engaged in criminal or terrorist activities. In the following section, which draws on my review of news articles, Hansard, and the cited Federal Court case, I will show how the discourse has shifted again. In 2009, official statements regarding the arrival of the Ocean Lady did not convey the pro-refugee attitudes that prevailed in 1986. Rather, the discourse focused on the threat of terrorism and criminality and the need to make Canada's refugee policies more restrictive.

\section{Part III. The Ocean Lady Incident}

On October 16, 2009, Canadian authorities intercepted the Ocean Lady, a cargo ship carrying 76 Sri Lankan Tamil men, off the coast of British Columbia. The RCMP had been alerted to the ship by international "security partners."78 After following the ship for approximately twenty hours, an RCMP emergency response team seized the vessel and guided it to Victoria with the assistance of the Canadian Navy. ${ }^{79}$ Once the ship was docked, the Canadian Border Services Agency CBSA took the ship's 76 passengers into custody ${ }^{80}$ and conducted initial admissibility interviews and medical examinations at the cruise ship terminal. ${ }^{81}$ The following day, the men were transported to a Vancouver detention facility. ${ }^{82}$ It is not publicly known whether the men have formally applied for refugee protection. However, two of the Ocean Lady passengers communicated through their lawyer that they indended to pursue refugee claims. ${ }^{83}$ Also, considering the widespread persecution of Tamils in Sri Lanka, it is reasonable to assume that the men would have exercised their right to make a claim for protection.

All of the 76 men were initially kept in custody because they lacked documentation and were deemed flight risks. ${ }^{84}$ Pursuant to s. 57(1) of the Immigration and Refugee Protection Act (IRPA), when a foreign national is taken into detention, the IRB must hold a detention review within forty-eight hours "or without delay afterward" and determine whether continued detention is warranted. ${ }^{85}$ In the case of the Ocean Lady passengers, although they were placed in detention on October 17, it was not until October 23 that all of the 76 men had appeared before the IRB for a detention review. ${ }^{86}$

During question period in the House of Commons on October 20, MP Don Davies (Vancouver Kingsway, NDP) highlighted the plight of Tamils in Sri Lanka and accused Ottawa of obstructing the migrant's access to legal counsel:

Mr. Speaker, the Sri Lankan government is making life unbearable for the Tamil population [ ... ] Now there are 76 Tamil refugees on the coast of British Columbia and we are hearing that the right to counsel within 48 hours is being violated. Will (Minister Kenney) ensure that this is corrected and that there is fast, fair and legal adjudication of these men's claims?87

Kenney rejected this allegation, and stated that the refugees were being processed in full accordance with the IRPA. ${ }^{88}$

On October 23, 2009, the media reported that one of the Tamil refugees, named Kartheepan Manickavasagar, was the subject of an Interpol notice issued by the Sri Lankan government. He was reportedly wanted for an "unspecified terrorism offence" and was suspected of being involved with the Tamil Tigers. Manickavasagar was also alleged to have been a member of an elite suicide squad of the Tamil Tigers called the Black Tigers. According to the Sri Lankan Criminal Investigation Department, it had been looking for him since September of $2008 .^{89}$ In response to these reports, Canadian Tamil Congress spokesman David Poopalapillai said that the charges against Manickavasagar should be treated with caution since the Sri Lankan government often wrongly accuses ethnic Tamils of terrorism. ${ }^{90}$

In early November, the IRB adjourned the detention review of a dozen of the 76 Tamils because CBSA indicated 
that it would be seeking their continued detention on security grounds. ${ }^{91}$ According to Lee Rankin, a lawyer representing some of the refugees, the alleged security threat was based on trace amounts of plastic explosives that had been found on the Ocean Lady, news clippings linking the vessel to the Tamil Tigers, and a terrorism expert's theory that the ship had been part of the Tamil Tigers' weapons-smuggling fleet. $^{92}$

On December 16, 2009, the IRB ordered approximately 50 of the men to be released with conditions. The Minister of Citizenship and Immigration (the Minister) challenged the release of one of the men in order to keep him in detention while officials continued to investigate his suspected association with the Tamil Tigers. On February 2, 2010, the Federal Court in Vancouver granted the Minister's application for judicial review, which meant that the subject of the release order, referred to as XXXX in the judgment, remained in custody. ${ }^{93}$

Writing on behalf of the Federal Court in M.C.I. v. $X X X X$, Barnes J. stated that the IRB misinterpreted the scope of its authority under s. 58(1)(c) of the IRPA. Pursuant to $\mathrm{s.} 58(1)(\mathrm{c})$, the IRB must order the release of a foreign national unless it is satisfied that the Minister is taking necessary steps to inquire into a reasonable suspicion that they are inadmissible on security grounds. The presiding IRB member reviewed the government's allegations, and determined that that there was insufficient evidence linking XXXX to the Tamil Tigers. While the member accepted that it was possible that the Ocean Lady belonged to the Tamil Tigers and that several of the passengers were likely Tamil Tigers members, he found that there was no evidence that connected XXXX personally to the terrorist group. ${ }^{94}$ Further, the member found that the Minister's proposed steps were unlikely to give rise to new information that would substantiate the suspicion. For example, the member questioned the likelihood that additional swabbing for traces of explosives on the ship would implicate XXXX, especially since he was not one of the two passengers found with traces on his clothing. ${ }^{95}$

According to Barnes J., the IRB member did not have authority to determine that the Minister's suspicion regarding XXXX was unreasonable. Based on a plain reading of s. 58(1)(c), wrote Barnes J., the IRB must defer to the Minister on this issue. The provision does not grant the IRB authority to conduct a de novo assessment of the evidence and decide for itself whether a reasonable suspicion exists. ${ }^{96}$ As such, the IRB member could only have determined that the Minister's suspicion was unreasonable if it was based on nothing more than "bare intuition or pure speculation." 97 In this case, said Barnes J., the government's suspicion was based on objectively ascertainable facts, and so it could not be said that it was unreasonable. Barnes J. held that the IRB's inquiry should have focused on whether the Minister was taking necessary steps to verify the suspicion. ${ }^{98}$ In closing, Barnes J. wrote:

(w)hile the importance of not unduly detaining such persons cannot be forgotten, the protection of Canadians and Canada's pressing interest in securing its borders are also worthy considerations. The government cannot use s. 58(1)(c) as the basis for indefinitely detaining foreign nationals, but it is entitled to a reasonable time to complete its admissibility investigation. ${ }^{99}$

Since this decision was released, all of the 76 Ocean Lady passengers have been released from custody, some with strict conditions. ${ }^{100}$

Based on my review of the newspaper articles and parliamentary debates surrounding the Ocean Lady incident, I identify three main themes: (1) concerns about human smuggling; (2) protectiveness of the integrity of the immigration system; and (3) concerns about security and criminality. Humanitarianism, which stood out as the dominant concern in 1986, was notably absent from the official discourse surrounding the arrival of the Ocean Lady. In some respects, the 2009 discourse appears to have more in common with the discourse in 1914. For example, just as in 1914, public officials characterized the Ocean Lady passengers as criminals who posed a threat to both the integrity of the immigration system and public safety.

Given the distinct historical and legal contexts in 1914 and 2009, concerns about the integrity of the immigration system and public safety were presented somewhat differently. In 1914, the integrity of the immigration system was an overtly racial issue as public officials defended laws that excluded the Komagata Maru passengers on the basis of their race. The characterization of the passengers as criminals was also clearly rooted in racist views about Asian migrants. In 2009, although racism was arguably still a factor, it was no longer explicit. In defence of the integrity of the immigration system, officials focused on the need to curb "abuse" of the refugee system by economic migrants posing as asylum seekers. On its face, this argument is racially neutral, although the alleged "abusers" are invariably people of colour. Public officials' concerns about criminality in 2009 were also less overtly racist than they were in 1914, although it is undeniable that the Ocean Lady passengers were suspected of being security threats because of their ethnicity and country of origin.

Early reports of the Ocean Lady highlighted concerns about human smuggling. The day after the Ocean Lady was seized, Peter Van Loan, the Minister of Public Safety, stated: "(o)bviously, they are arriving in a non-conventional fashion 
so that raises concerns ... of human smuggling." 101 He continued: "( $\mathrm{t}$ )he CBSA is working with domestic and international partners to combat irregular migration to Canada, including smuggling and trafficking in persons."102 With these statements, Van Loan characterizes the Ocean Lady passengers as victims of human smuggling, and conveys that human smuggling is a crime that Canada takes seriously and is working to combat. He also indicates that one of the reasons for combating human smuggling is to prevent unauthorized migrants from entering Canada.

On October 19, Immigration Minister Kenney told the Globe and Mail that human smuggling is a growing problem and that the illegal arrival of the Ocean Lady highlights the need for stricter enforcement. ${ }^{103}$ In another statement to the press, Kenney said:

(w)e obviously don't want to encourage people to get into rickety boats, pay thousands of dollars, cross the oceans and come to Canada illegally. [ ... ] Without prejudice to this particular group of people, all I can say is that as a country we need to make sure we are not creating a kind of perverse incentive for people to try to come to the country through these kind of really dangerous circumstances. ${ }^{104}$

In this statement, Kenney appears to want to convey concern for the safety and well-being of the Ocean Lady passengers. At the same time, Kenney implies that Canada should not offer protection to these individuals so as not to encourage others to follow in their footsteps. Therefore, like the statements regarding human smuggling, this statement appears to be focused on securing Canada's borders and protecting the integrity of the immigration system.

These statements regarding the government's commitment to curb human smuggling and illegal migration to Canada point to an interesting question: did Canadian authorities know that the Ocean Lady was carrying unauthorized migrants bound for British Columbia before it entered Canadian waters? And if so, why did they choose not to intercept the vessel earlier? From the media reports, it is unclear at what point Canadian officials detected the Ocean Lady. On October 18, the Toronto Star reported that the Ocean Lady was already in Canadian waters on the October 15, which means that the ship may have already been in Canadian waters when the RCMP began to follow it. ${ }^{105}$ On November 24, however, the Toronto Globe and Mail reported that a CBSA officer said he learned the migrant ship was on its way to Canadian waters two days before it arrived. According to the officer, ships as large as the Ocean Lady are required to notify a coast guard ninetysix hours before arriving. When the ship failed to do so, a federal fisheries airplane was sent to observe it. ${ }^{106}$ Based on this report, it seems possible that Canadian authorities were aware of the ship before it entered Canadian waters.

If the Ocean Lady had in fact been detected in international waters, authorities could have intercepted it before the migrants had entered Canadian territory and thereby prevented them from gaining access to the refugee determination system. Like most developed countries, Canada implements interdiction measures to prevent unauthorized migrants from entering Canadian territory and thereby gaining access to the inland refugee determination process. ${ }^{107}$ These measures include screening passengers in airports overseas before permitting them to board planes bound for Canada. Some states, such as Australia and the United states, also track down and intercept vessels suspected of carrying unauthorized migrants at sea. ${ }^{108}$ Although Canada is not known to engage in maritime interception independently, it has been involved in interception missions in partnership with other states. ${ }^{109}$

Interception is controversial because the Refugee Convention obliges signatory states to refrain from returning refugees to countries where they could face persecution. ${ }^{110}$ Some state parties have taken the view that this obligation is only triggered at the moment when an individual sets foot on the state's territory. Some scholars, however, advance the view that the obligation not to return a refugee to a country where s/he may face persecution includes the obligation not to intercept and deflect refugees before they arrive in the state's territory. ${ }^{111}$ It is possible that the Canadian government chose not to intercept the Ocean Lady because it wanted to avoid opening up the question of whether or not such an action would contravene the Refugee Convention. This of course, is merely speculation, as it is not possible to know for certain why Canadian authorities may have decided to allow the Ocean Lady enter Canadian waters. It is interesting to note that a conscious decision to permit the refugees to enter Canada illegally stands in contrast to the official rhetoric surrounding the incident, which implies that Canada takes border control seriously and is taking action to prevent and discourage illegal migration.

The themes of border control and the integrity of Canada's immigration system are also apparent in a set of public statements in which Kenney called for policy reforms to prevent abuse of the refugee system. Kenney stated that Canada does not want to develop a "two-tier immigration system" where some people wait patiently to immigrate to Canada, while others come to Canada illegally through the "back door." Many of those who enter Canada through the "back door," says Kenney, often do so by making a refugee claim, which is an abuse of the refugee system and unfair to those who come to Canada by legal channels. ${ }^{112}$ In making these arguments in relation to the Ocean Lady incident, 
Kenney implies that the passengers are among those trying to immigrate to Canada through the "back door." No account is made for the possibility that they may have wellfounded fear of persecution.

In addition to these arguments about the "two-tier immigration system," Kenney also took the opportunity to criticize Canada's refugee determination process as overly generous: "(w)hen a large number of people arrive off the coast in one boat, it attracts people's attention. But I can tell you there were airplanes arriving from Prague this summer where over half the passengers were going on to make asylum claims." 113 With this statement, Kenney appears to want to raise public alarm over the number of people making refugee claims in Canada. He characterizes the arrival of the Ocean Lady as a part of a larger problem of masses of foreigners seeking to make refugee claims in Canada.

Another theme in Kenney's statements regarding the Ocean Lady is security and the fear of terrorism. On October 21, Kenney announced that security authorities were investigating the Ocean Lady's passengers to determine whether they have connections to any terrorist organizations, in which case they would be inadmissible to Canada. ${ }^{114}$ Kenney's spokesperson, Alykhan Velshi, emphasized the government's commitment to deport any of the Ocean Lady passengers found to have terrorist connections or other criminal involvement:

(t)he government will strenuously argue that every single one of these individuals with terrorist or criminal backgrounds-and that includes membership in the murderous Tamil Tigers-is ineligible to make a refugee claim in Canada. [ ... ] We won't allow Canada to become a place of refuge for terrorist, thugs, snakeheads and other violent foreign criminals. Nor will we support those who want to create a two-tier immigration system: one tier for law-abiding immigrants who wait patiently in the queue, and a second, for-profit tier for criminals and terrorists who pay human smugglers to help them jump the queue. ${ }^{115}$

Although Velshi did not say that any of the Ocean Lady passengers have been confirmed to be associated with the Tamil Tigers, this statement carries a strong implication that such terrorist connections are possible if not likely. Velshi also links the issue of terrorism with the other concerns about human smuggling and violation of Canada's immigration laws. He suggests that those who pay human smugglers to help them enter Canada are "criminal and terrorists," and does not acknowledge that individuals fleeing persecution may also have to resort to such means of transportation.

\section{Part IV. Comparative Analysis}

The official statements examined in this paper do not offer a comprehensive picture of changes in refugee policy throughout Canadian history, and I do not mean to suggest that my research offers any definitive conclusions. Rather, I propose that this sample of official discourse provides snapshots of Canada's changing stance toward asylum seekers at three distinct points in history. In each section of the paper, I identified the main themes in the official discourse surrounding the three incidents. In this final section of the paper, I analyze the official discourse surrounding the three selected incidents, and consider the differences and similarities in the treatment of the following key issues: (1) security and criminality, (2) the integrity of the immigration system, and (3) humanitarianism.

\section{Security and Criminality}

Concerns about security and criminality played out in all three discourses, although in different ways. This theme appeared to be strongest in the official statements regarding the Komagata Maru incident. In this case, politicians characterized the Indian migrants as violent criminals who needed to be controlled with strong coercive measures. This situation is somewhat unique, however, because the Komagata Maru passengers did in fact resort to violent measures to resist their removal. However, the language of some of the statements, which depicted the migrants as "fanatical" and "desperately revolutionary and determined to defy the law," intimate the anti-Asian sentiments among Canadian officials at the time and therefore appear to be more than an objective observation of the passengers' violent actions. The depiction of the passengers as criminals was justified by the legal regime because as Indian migrants they were breaking the law simply by virtue of their presence in Canadian territory. In this sense, the 1914 discourse linked concerns about criminality to fears about racial threats to Canadian society. In short, Canadian officials were of the view that members of the "Asiatic races" had no place in Canadian society, and any Asian attempting to enter Canada would be treated as a criminal.

In contrast to 1914, when the migrants were criminalized due to their race, in 1986 and 2009 the discussions about security and criminality focused on fears about terrorism. Specifically, the refugees were feared to be members of the Tamil Tigers. In 1986, officials communicated to the public that the proper authorities were conducting background checks on the 155 Tamil refugees but that there was no evidence linking the individuals to terrorism or other criminal activities. Security concerns were considered to be less important than Canada's commitment to protecting refugees, and the refugees were presumed to be innocent until proven otherwise. 
In 2009, however, the official discourse evidences a reversal in the presumption; the refugees were presumed to be a threat until it could be established that they were not. The official discourse characterized the refugees as suspected terrorists. This was clear in the government spokesperson's comment that placed the Ocean Lady passengers in the same category as "terrorists, thugs, snakeheads and other violent foreign criminals." This shift in the rhetoric was mirrored by changes in the government's procedures for dealing with asylum seekers arriving by boat. In contrast to 1986, when the refugees were put up in a university dorm and then sent to stay with members of the Sri Lankan community, the Ocean Lady passengers were detained upon arrival and held in detention for several months as the government investigated their suspected terrorist links. In this sense, the emphasis on criminality that was apparent in 1914 incident seems to have been revived in the current context.

\section{Integrity of the Immigration System}

The issue of the integrity of the immigration system also featured in each of the three discourses. Before I discuss how this issue played out in each of the three incidents, it is worth exploring why refugee claimants are sometimes feared to pose a threat to the integrity of the immigration system. I contend that this fear flows from a desire to maintain control over national borders. Like most countries, Canada implements immigration laws that determine who will be selected to immigrate to the country and who will be denied. Unlike immigration applicants, however, asylum seekers are self-selected. When Canada signed the Refugee Convention, it committed itself to accept individuals with a well-founded fear of persecution, regardless of whether or not they meet the criteria to immigrate to Canada. In this sense, immigration law and refugee law are two separate systems that can both result in the admission of a foreign national. In the case of the immigration system, the government retains control over admissions, whereas with the refugee system, the government is obliged to accept any foreign national who arrives in Canadian territory and is found to meet the definition of Convention refugee. This difference appears to foster a sense of loss of control among public officials, which can result in calls for restrictions on the refugee system in order to strengthen the government's control over who will be admitted to the country.

In 1914, the integrity of the immigration system was understood in racial terms. The legal regime in place at the time was designed to exclude Asians generally, and Indian migrants specifically. Officials defended these restrictions as Canada's right to determine what type of people will be permitted to join Canadian society. This sentiment was particularly evident in the former Minister of the Interior's statement that Canada will not accept the dictation of other people as to who will join Canadian society. With this statement, the official made it clear that Canada would not welcome the Komagata Maru passengers who sought to enter Canada contrary to the immigration laws that explicitly excluded them. Maintaining the integrity of the immigration system meant ensuring that people like the passengers were kept out.

In 1986 and 2009, the issue of the integrity of the immigration system was no longer an explicitly racial issue. Instead, the issue took the form of discussions about the need for policy reform to limit the number of people who enter Canada through the refugee system. In 1986, officials addressed concerns among members of the Opposition that the refugee policies were too generous. While they acknowledged the need for policy reform, they emphasized that Canada must adhere to its humanitarian commitment to protect refugees. Like the security concerns, although fears about threats to the immigration system were acknowledged, they were minimized by the more pressing concern of the refugee claimants' need for protection from persecution.

In the 2009 discourse, however, officials placed a much stronger emphasis on the need to restrict the flow of refugees to Canada. This is apparent in Minister Kenney's comments in which he suggests that the Ocean Lady passengers sought to use the refugee system as a "back door" to immigrate to Canada. With these comments, Kenney recharacterizes refugee claimants as immigrants looking for an easy way to enter Canada. Viewed through this lens, the refugee is no longer an individual fleeing persecution, but rather an illegal immigrant who poses as a victim of persecution in order to remain in the country. Kenney also made statements indicating that this kind of abuse of the refugee system creates a "two-tier immigration system," which is unfair to individuals who wait patiently as their immigration applications are being processed.

Kenney's statements in response to the arrival of the Ocean Lady echo Macklin's observation that the discursive disappearance of the refugee involves the conceptual differentiation between "real refugees" and "illegals." The "real refugee" is conceived as a person who lives somewhere else, for example in a refugee camp overseas. Once this person crosses a border into a developed country, says Macklin, they cease to be a refugee and transform into an "illegal," even though the IRPA explicitly states that refugee claimants are not to be prosecuted for unauthorized entry into the country. 116 Unlike refugees, "illegals" are transgressors who have no right to enter or remain in the country. ${ }^{117}$ Kenney's statements reflect this discursive transformation because they imply that refugee claimants like the Ocean 
Lady passengers are not "real" refugees, but rather illegal immigrants attempting to come through the "back door."

The discursive disappearance of the refugee is also apparent in the government spokesperson's statement that refers to refugee claimants as "queue jumpers." Like the "back door" comment, this statement suggests that claimants use the refugee system as an easy way to immigrate. Moreover, it implies that these individuals should not make refugee claims but rather wait in the queue for their turn to immigrate to Canada. This suggestion is nonsensical because the refugee and immigration processes are entirely separate systems. In other words, immigrants and refugees are not in the same queue. Moreover, as the Minister of State for Immigration pointed out in 1986, refugees "cannot wait for a number" because they are fleeing persecution. Referring to claimants as queue jumpers blurs the distinction between refugees and immigrants, and shifts the discourse away from Canada's obligation to protect refugees.

\section{Humanitarianism}

The theme of humanitarianism relates directly to the issue of Canada's commitment to the cause of refugees. The extent to which this theme played out in each of the discourses provides an indication of the strength of the concept of the refugee at the relevant time. In 1914, the official actors did not consider the possibility that the Komagata Maru passengers should be admitted on humanitarian grounds. Given that the incident took place several decades before the Refugee Convention came into existence, the legal regime did not contemplate doing so. Furthermore, the racist immigration policies of the day justified their exclusion, and apparently enjoyed the support of non-Asian members of the Canadian public.

As I explained at the outset of this paper, I decided to include a discussion of the Komagata Maru incident in order to provide a picture of Canada's reception of asylum seekers prior to the coming into force of the Refugee Convention. This picture, compared to the situation in 1986, provides a remarkable contrast. In 1986, the issue of humanitarianism dominated the official discourse surrounding the arrival of the Tamil asylum seekers. Although officials gave credence to concerns about security and the integrity of the immigration system, they strenuously defended Canada's legal and moral obligation to protect those fleeing from persecution.

Compared to 1986, the issue of humanitarianism is strikingly absent from the official discourse in 2009. Concerns about security and threats to the integrity of the immigration system came to the fore. None of the official statements that I found in the media and parliamentary debates included an explicit reference to the importance of upholding Canada's humanitarian tradition.

\section{Conclusion}

Overall, the materials that I have reviewed in this paper support Macklin's theory of the discursive disappearance of the refugee. The three selected incidents trace the emergence and decline of the notion of the refugee in Canadian official discourse. In 1914, Canadian officials communicated no concern for the possibility that the Komagata Maru passengers were in need of protection, and the idea of allowing them to remain in Canada on humanitarian grounds was not entertained. In 1986, by contrast, the issue of humanitarian and Canada's moral and legal obligation to protect refugees became public officials' dominant concern. The 2009 incident reflected yet another shift in the discourse. Although the Ocean Lady passengers were legally entitled to make refugee claims, the theme of humanitarianism was almost entirely eliminated from the discourse and public officials branded the claimants as illegal migrants. As in 1914, the officials in 2009 focused on concerns about security and the integrity of the immigration system. Canada's dedication to the Refugee Convention, which appeared so strong in 1986, became a mere footnote in the discourse.

This process of the rise and fall of the concept of the refugee, however, was not entirely clear-cut. As I discussed in Part II, although humanitarianism dominated the discourse in 1986, officials also expressed concerns about security and the integrity of the immigration system. Public officials referred to asylum seekers as possible security threats and spoke of the need to prevent foreigners from "jumping to the head of the line" by taking advantage of the refugee system. ${ }^{118}$ For this reason, it is perhaps inaccurate to regard the disappearance of the refugee as only a recent phenomenon. Even during the heyday of Canada's refugee policy, the idea that an asylum seeker may just be an economic migrant in disguise was already apparent in the official discourse. In this sense, it appears that the concept of the refugee has always been vulnerable to the nullifying discourse of the illegal migrant. What we see in 2009 is merely the intensification of the discursive disappearance of the refugee, which is a process that has been in place for some time.

Procedurally, Canada continues to uphold its obligation to process refugee claims to determine whether or not individuals have a well-founded fear of persecution. However, the recent shift in the official discourse is cause for concern as it conveys a decline in political commitment to maintaining this robust process. Indeed, the current government has recently introduced an overhaul of the refugee determination process aimed at making the system more efficient and less vulnerable to abuse. ${ }^{119}$ Given the context of the shift in rhetoric, this legislative change recalls Macklin's warning that the discursive erasure of the refugee could serve as a "preparatory step toward legitimating actual laws 
and practices that attempt to make them vanish in reality." 120 Although the potential impact of the new procedures remains uncertain, Macklin's bleak prediction may prove to be apt. With reports of another ship carrying asylum seekers heading for Canadian shores, it appears that Canada's commitment to the Refugee Convention may be tested once again. ${ }^{121}$

\section{Notes}

1. Catherine Dauvergne, Humanitarianism, Identity, and Nation: Migration Laws of Australia and Canada (Vancouver: University of British Columbia Press, 2005) at 5 and 163.

2. Convention relating to the Status of Refugees, 28 July 1951, 189 U.N.T.S. 150, Can. T.S. 1969/6 (entered into force 22 April 1954, accession by Canada 2 September 1969).

3. Supra note 1 at 163-164.

4. Sharryn J. Aiken, "Of Gods and Monsters: National Security and Canadian Refugee Policy" (2001) 14 R.Q.D.I. 2 at 2; Dauvergne, supra note 1 at 220; Valerie Knowles, Strangers at Our Gates: Canadian Immigration and Immigration Policy, 1540-2006 (Toronto: Dundurn Press, 2007) at 247; Audrey Macklin, "Disappearing Refugees: Reflections on the Canada-U.S. Safe Third Country Agreement” (2005) 36 Columbia Hum. Rights. L. Rev. 365, at 365.

5. Macklin, supra note 4.

6. Supra note 1 at 220-221.

7. Harald Bauder, "Immigration Debate in Canada: How Newspapers Reported, 1996-2004” (2008) Int. Migration \& Integration 9 at 292; Knowles, supra note 4 at 222.

8. Knowles, supra note 4 at 223.

9. Marian Scott, "Black july' 1983 marks the start of full-scale war in Sri Lanka" The Gazette (2 May 2009), (ProQuestCanadian Newsstand).

10. "After war, war measures" The Globe and Mail (28 May 2009), (ProQuest-Canadian Newsstand).

11. Hugh J. M. Johnston, The Voyage of the Komagata Maru: The Sikh Challenge to Canada's Colour Bar (Vancouver: University of British Columbia Press, 1989) at 114.

12. "B.C. apologizes for Komagata Maru incident" CBC News (23 May 2008) (ProQuest-Canadian Newsstand).

13. Ibid.

14. Dirk Meissner, "94 years later, and apology to South Asian migrants" The Globe and Mail (24 May 2008) (ProQuestCanadian Newsstand).

15. Karen Musalo et al., eds., Refugee Law \& Policy: A Comparative and International Approach, $3^{\text {rd }}$ ed. (Durham: Carolina Academic Press, 2007) at 5.

16. "Hannah Arendt, The Origins of Totalitarianism," excerpts from "The Decline of the Nation State and the End of the Rights of Man" from Hannah Arendt, The Origins of Totalitarianism (Harcourt Brace, 1951), reprinted in Karen Musalo et al., eds., Refugee Law \& Policy: A Comparative and International Approach, $3^{\text {rd }}$ ed. (Durham: Carolina Academic Press, 2007) at 16.

17. Ibid.

18. Re Munshi Singh, [1914] B.C.J. No. 116, 6 W.W.R. 1347, 20 B.C.R. 243 (BCCA).

19. Ibid.

20. Ninette Kelley \& Michael Trebilcock, The Making of the Mosaic: A History of Canadian Immigration Policy (Toronto: University of Toronto Press, 1998) at 151.

21. Eric W. Morse, "Some Aspects of the Komagata Maru Affair, 1914" in Canadian Historical Association, Report of the Annual Meeting Held at Ottawa, May 26-27, 1939 (Toronto: University of Toronto Press, 1936) at 104.

22. Supra note 20 at 151.

23. Supra note 11 at 57.

24. Ibid. at 58.

25. Supra note 20 at 50.

26. Supra note 11 at 58.

27. Supra note 20 at 150.

28. Supra note 21 at 101.

29. Supra note 20 at 105.

30. Supra note 11 at 38.

31. Supra note 21 at 103.

32. Supra note 11.

33. Supra note 20 at 151.

34. Supra note 18.

35. Supra note 11 at 63.

36. Ibid. at 72 .

37. Ibid. at 72 .

38. Ibid. at 76-78.

39. Supra note 21 at 104.

40. Ibid. at 105-106.

41. Supra note 11 at 79.

42. Supra note 21 at 106.

43. Supra note 8 at 121.

44. Supra note 11 at $102-104$.

45. Ibid. at 108 .

46. Ibid. at 114

47. Ibid. at 114 .

48. The media initially reported that the lifeboats carried 152 individuals. This number was later changed to 155 ; see Joe Serge, "Metro Tamils Open Homes for Brethren Found at Sea" Toronto Star (14 August 1986), (ProQuest-Canadian Newsstand).

49. Ron Lowman, "152 castaways rescued by fishermen after 5 days adrift off Newfoundland" The Toronto Star (12 August 1986), (ProQuest-Canadian Newsstand).

50. "Refugees survive ordeal at sea: 152 Sri Lankans set adrift in lifeboats off Nfld. Coast" The Ottawa Citizen (12 August 1986), (ProQuest-Canadian Newsstand).

51. Graham Fraser \& Robert Martin, "152 can stay if nationality is confirmed" The Globe and Mail (13 August 1986), (ProQuest-Canadian Newsstand). 
52. Joseph Hall \& Alan Story, "Refugees standing by story they came on ship from India" Toronto Star (13 August 1986), (ProQuest-Canadian Newsstand).

53. Supra note 46 .

54. Christopher Waddell, "No means to track 155 Tamil refugees once permits expire" The Globe and Mail (16 August 1986), (ProQuest-Canadian Newsstand).

55. Graham Fraser, "Tamils wouldn't be deported, Bouchard says" The Globe and Mail (11 February 1987), (ProQuestCanadian Newsstand).

56. David Vienneau, "No more 'adventures' Ottawa tells refugees” Toronto Star (14 August 1986), (ProQuest-Canadian Newsstand).

57. "Tamils involved in criminal acts will be deported, minister vows" The Gazette (20 August 1986), (ProQuest-Canadian Newsstand).

58. Robert Lee Citizen. "Govt. tipped refugee ship was coming” The Ottawa Citizen (16 August 1986), (ProQuestCanadian Newsstand).

59. Ibid.

60. Supra note 52.

61. "PM defends entry permits amid uproar" The Ottawa Citizen (18 August 1986), (ProQuest-Canadian Newsstand).

62. "Govt. fears refugees will encourage others" The Ottawa Citizen (13 August 1986), (ProQuest-Canadian Newsstand).

63. Supra note 62.

64. Joe O’Donnell, "Ship eluded dragnet despite early tip-off" Toronto Star (16 August 1986), (ProQuest-Canadian Newsstand).

65. Ibid.

66. Joseph Hall, "Group 'regrets' lying to Canada spokesman says" Toronto Star (17 August 1986), (ProQuest-Canadian Newsstand).

67. Joe O'Donnell, "Show compassion for Tamil refugees Mulroney urges" Toronto Star (18 August 1986), (ProQuest-Canadian Newsstand).

68. Ibid.

69. Supra note 57.

70. Ibid.

71. Ibid.

72. Ibid.

73. Joe O’Donnell, “Some Tamils could face deportation Ottawa says" Toronto Star (19 August 1986), (ProQuestCanadian Newsstand).

74. Supra note 56.

75. Supra note 62.

76. "Leaders attempt to fight off litany of bad news; Tamil decision right despite mistakes: PM" The Ottawa Citizen (6 September 1986), (ProQuest-Canadian Newsstand).

77. Phinjo Gombu, "5-year wait taking toll on Tamil boat people” Toronto Star (11 August 1991), (ProQuestCanadian Newsstand).

78. "RCMP seize vessel on human smuggling tip; 'Security partners' raise alert to ship found off B.C. coast" The
Ottawa Citizen (18 October 2009), (ProQuest-Canadian Newsstand).

79. Ibid.

80. Mathew Pearson, "Ship with 76 on board intercepted; Rusting vessel's seizure could be a case of human smuggling" The Province (18 October 2009), (ProQuest-Canadian Newsstand).

81. Petti Fong, "76 illegal migrants found on ship seized off B.C.; Barefoot, bare-chested individuals on board say destination was Canada" Toronto Star (18 October 2009), (ProQuest-Canadian Newsstand).

82. Petti Fong, "Migrants said to be Tamils; 76 men on merchant ship seized off coast of B.C. are asylum-seekers, Canadian Tamil group says" Toronto Star (19 October 2009), (ProQuest-Canadian Newsstand).

83. Stewart Bell \& Brian Hutchinson, "Canada tipped off to ship; 'Foreign intelligence' tracked migrants" National Post (21 October 2009), (ProQuest-Canadian Newsstand).

84. Jane Armstrong \& Jill Mahoney, "Sri Lankan migrants suffered grueling journey" The Globe and Mail (22 October 2009), (ProQuest-Canadian Newsstand).

85. Immigration and Refugee Protection Act, S.C. 2001, c. 27, s. 57(1).

86. Cassidy Olivier, "Advocates call for release of Sri Lankan immigrants" The Province (25 October 2009), (ProQuestCanadian Newsstand).

87. Canada, Parliament, Edited Hansard, No. 096, $40^{\text {th }}$ Parliament, $2^{\text {nd }}$ Session (October 20, 2009).

88. Ibid.

89. Stewart Bell, "Sri Lankan migrant wanted for smuggling; Accused of working for Tamil Tigers" National Post (26 October 2009), (ProQuest-Canadian Newsstand).

90. Stewart Bell, "Cargo ship passenger wanted in Sri Lanka for terrorism; Subject of Interpol notice wanted for unspecified offence among 76 migrants detained after arriving off B.C. coast Saturday" The Vancouver Sun (23 October 2009), (ProQuest-Canadian Newsstand).

91. Stewart Bell, "Tamils' ship alleged to have traces of explosives; Suspected gunboat" National Post (3 November 2009), (ProQuest_Canadian Newsstand).

92. Ibid.

93. Canada (Minister of Citizenship and Immigration) v. XXXX, 2010 FC 112, F.C.J. No. 128.

94. Ibid. at para. 5.

95. Ibid. at para. 6 .

96. Ibid. at para. 14 .

97. Ibid. at para. 15 .

98. Ibid. at para. 18 .

99. Ibid. at para. 21.

100. Chad Skelton, "Border Services has no proof migrants were terrorists; Statement contradicts secret report alleging 25 of the Sri Lankans captured last October were Tamil Tigers" The Vancouver Sun (10 July 2010), (ProQuest-Canadian Newsstand).

101. Supra note 80 . 
102. Supra note 81

103. Jane Armstrong \& John Ibbitson, "Seeking a safe haven, finding a closed door" The Globe and Mail (20 October 2009), (ProQuest-Canadian Newsstand).

104. Norma Greenaway, "Minister determined to fight 'human smuggling': Refugee claims will be handled as usual, he says" The Vancouver Sun (21 October 2009), (ProQuestCanadian Newsstand).

105. Supra note 81.

106. Jane Armstrong, "Traces of explosives potential danger to Tamils' case" The Globe and Mail (24 November 2009), (ProQuest-Canadian Newsstand).

107. Aiken, supra note 2 at para. 47.

108. Ibid.

109. Andrew Brouwer \& Judith Kumin, "Interception and Asylum: When Migration Control and Human Rights Collide" (2003) 21:4 Refuge 6.

110. Supra note 2.

111. Supra note 107 at para. 48.

112. Supra note 103
113. Ibid.

114. Supra note 104.

115. Supra note 90.

116. Supra note 85 , s. 133.

117. Supra note 5 at 369.

118. Supra note 67.

119. Dave Bartlett, "Immigration minister promotes refugee reforms: Jason Kenney on cross-Canada tour" The Telegram (6 April 2010), online: The Telegram http://www .thetelegram.com/index.cfm?sid $=335449 \& s c=79$.

120. Supra note 5 at 369.

121. Stewart Bell, "Canada Monitors Suspicious Vessel; May be carrying migrants to B.C. coast: report" National Post (16 July 2010), (ProQuest-Canadian Newsstand).

Alexandra Mann holds a Juris Doctor from Osgoode Hall Law School and a Bachelor of Arts in International Development Studies and Political Science from Dalhousie University. She is currently articling at the HIV/AIDS Legal Clinic of Ontario. 